\title{
Alternatif Kebijakan Operasional Dalam Menurunkan Kejadian Turnover Perawat di RSDH Cianjur
}

\author{
Mohamad Yaser $^{1}$ dan Hafizurrachman ${ }^{2}$ \\ ${ }^{1}$ Program Studi Pascasarjana Ilmu Kesehatan Masyarakat \\ ${ }^{1,2}$ Sekolah Tinggi Ilmu Kesehatan Indonesia Maju \\ Alamat : Jln.Harapan No.50 Lenteng Agung, Jakarta Selatan \\ email: yaserhb197@gmail.com ${ }^{1}, \underline{\text { hafizurrachman@gmail.com }}^{2}$
}

\begin{abstract}
ABSTRAK
Turnover perawat merupakan yang ditempuh oleh perawat untuk meninggalkan rumah sakit atau perusahaan dimana perawat bekerja. Angka kejadian turnover di RSDH Cianjur terjadi peningkatan setiap tahunnya. Penelitian ini bertujuan untuk mengidentifikasi penyebab terjadinya turnover perawat dan menyusun alternatif kebijakan operasional yang akan digunakan untuk menurunkan angka kejadian turnover perawat. Informan yang digunakan dalam penelitian ini sebanyak 5 orang sebagai infoman kunci, dan 10 orang sebagai informan pendukung yang diambil dengan teknik purposive sampling. Rancangan penelitian dengan menggunakan study fenomenology. Tema yang terdidentifikasi terkait dengan turnover perawat meliputi : faktor penyebab turnover perawat, faktor penyebab lain terkait turnover, faktor yang membuat bertahan, perasaan saat bekerja, dan alasan perawat baru bekerja di RSDH Cianjur. Penyusunan alternatif kebijakan yang akan digunakan untuk menurunkan angka kejadian turnover perawat disesuaikan dengan prioritas masalah yang telah ditetapkan. Adapun kebijakan yang diajukan ke manajemen RSDH Cianjur untuk menurunkan angka kejadian turnover perawat adalah dengan memperbaiki sistem penggajian yang disesuaikan dengan tingkat pendidikan dan lama bekerja.
\end{abstract}

Kata kunci : Turnover, Perawat, Kebijakan Operasional

\begin{abstract}
Turnover nurses is covered by nurse to from hospital or company where nurses work. Incidence turnover in RSDH Cianjur increased every year.Research aims to identify the cause of turnover nurses and develop alternative operational policy to be used to lower incidence turnover nurse.Sources who used in this research about 5 people as infoman key, and 10 people as informants advocates taken to technique purposive sampling.The research with the use study fenomenology. A theme that terdidentifikasi associated with turnover nurses covering: the causes of turnover nurse, the causes of other related turnover, to the survive, feeling while working, and the reason new nurses work in RSDH Cianjur. The preparation of alternative measures which would used to lower incidence turnover nurse adapted to priority matter that has been set. As for policy go to management RSDH Cianjur to lower incidence turnover nurse is to improving the system of penggajian adjusted with the education level and many years working .
\end{abstract}

Keywords: turnover, nurses, operational policy 


\section{Pendahuluan}

Rumah sakit merupakan salah satu bentuk sarana kesehatan bagi masyarakat yang diselenggaran oleh pemerintah maupun swasta yang tugas memberikan pelayanan kesehatan dasar maupun rujukan atau melakukan kesehatan penunjang. ${ }^{1}$ Pertumbuhan dan perkembangan rumah sakit dalam 20 tahun belakangan ini meningkat pesat, hal ini menimbulkan persaingan yang semakin ketat antar rumah sakit. Perubahan yang terjadi dalam masyarakat saat ini sangat mempengaruhi persaingan tersebut, baik perubahan demografi, sosial ekonomi, IPTEK, kompetisi pasar maupun sumber daya manusianya. ${ }^{2}$ Pada tahun 2020, diperkirakan akan ada kekurangan hampir 1 juta perawat di Amerika Serikat. Hal ini di sebabkan karena terjadinya pertumbuhan industri kesehatan yang terus menerus melebihi kebutuhan perawat yang tersedia dan peningkatan angka turnover di masa yang akan datang. ${ }^{3}$

Hal ini di dukung oleh laporan hasil survei di fasilitas keperawatan yang dilakukan oleh American Healt Care Association (AHCA) tahun 2011, ada sekitar 2 juta pekerja yang bekerja di fasilitas keperawatan di seluruh Amerika Serikat pada tahun 2010, dimana staf perawat berjumlah 1,3 juta staf (66 persen). Tingkat turnover tertinggi berada pada staf perawat sebesar 39,5 persen dari jumlah total turnover karyawan sebesar 35,1 persen. Tingkat turnover untuk Staf Perawat Terdaftar (RN), Izin Perawat Praktis (LPN), dan CNA berkisar 34,7- 42,6 persen. Tingkat turnover untuk Direktur Keperawatan (DON) dan Perawat Terdaftar dengan Tugas Administrasi (ARN) adalah 26,0 dan 28,9 persen (AHCA, 2011)., dimana ditemukan bahwa turnover juga merupakan masalah utama di rumah sakit di Kanada dengan tingkat turnover rata-rata $19,9 \%{ }^{4}$

Tingginya kejadian turnover pada perawat dapat terjadi disetiap institusi rumah sakit, dan masalah turnover perawat terjadi di RSDH Cianjur di bagian sumber daya manusia RSDH Cianjur diperoleh data kejadian turnover pegawai dan rekrutment dari tahun 2009 sampai
2013 sebagai berikut : pada tahun 2009 kejadian turnover perawat sebanyak 5 orang $(9,01 \%)$, tahun 2010 kejadian turnover pegawai sebanyak 3 orang $(5,4 \%)$, tahun 2011 kejadian turnover pegawai sebanyak 7 orang $(12,7 \%)$, tahun 2012 kejadian turnover perawat sebanyak 7 orang (12,7\%), dan tahun 2013 terhitung dari bulan januari sampai dengan oktober kejadian turnover perawat sebanyak 13 orang $(23,6 \%)$. Jadi dapat disimpulkan bahwa kejadian turnover pegawai di RSDH Cianjur semakin meningkatnya dari tahun ke tahun bahwa turnover perawat maksimal $12 \%$ per tahun sedangkan turnover perawat maksimal $5-10 \%$ per tahun. ${ }^{5}$

Asumsi pegawai RSDH Cianjur kait kompensasi yang mereka terima setiap bulannya adalah dengan memiliki kemampuan, keahlian dan pengalaman kerja di bidang kardiovaskuler, perawat bersangkutan akan mendapatkan kompensasi yang lebih baik dan lebih besar di tempat yang baru. Selain alasan kompensasi, terdapat beberapa faktor lain yang bisa menyebabkan seseorang untuk pindah bekerja dan terjadi fenomena turnover yang tinggi mencapai 18 karyawan diantaranya 7 perawat di RSDH Cianjur maka rumusan masalah tentang tingginya angka kejadian dan kebijakan kompesasi menjadi faktor yang paling berkaitan dengan turnover perawat peneliti tertarik mengadakan penelitian. Terkait masalah turnover tenaga perawat di RSDH Cianjur hasil penelitian ini memberikan implikasi pada manajemen keperawatan untuk lebih meningkatkan kinerja perawat dan menciptakan lingkungan kerja yang baik bagi perawat.

Penelitian ini juga memberikan sumbangan kajian teoritis pada ilmu pengetahuan khususnya organisasi rumah sakit mengenai turnover tenaga perawat serta memberi masukan bagi rumah sakit untuk memperbaiki sistem rekrutment dan sistem penggajian sehingga dapat mencegah terjadinya peningkatan turnover tenaga perawat yang merugikan rumah sakit maupun perawat. Ada pun tujuan Penelitian ini adalah Menyusun alternatif kebijakan operasional yang akan 
digunakan untuk menurunkan angka kejadian turnover perawat di RSDH Cianjur. ${ }^{6}$

\section{Metode}

Desain penelitian ini termasuk jenis penelitian analisis kualitatif studi dokumentasi, wawancara mendalam (indepth interview), obsevasi, melakukan Focus Group Discussion dan catatan lapangan (filed notes). studi deskriptif fenomenologi yaitu suatu strategi penelitian dimana peneliti mengeksplorasi pengalaman manusia terhadap suatu kejadian atau fenomena tertentu, dan peneliti harus mengkaji secara langsung dan detail kepada beberapa informan. ${ }^{7}$

Penelitian ini dilaksanakan di RSDH Cianjur. Pemilihan lokasi penelitian ini dilakukan dengan pertimbangan bahwa ditemukan tingginya angka kejadian turnover perawat. Sasaran Penelitian ini adalah perawat yang masih bekerja yang terdiri dari 2 Informan dan Informan kunci dilihat dari tabel:

Tabel 1 Karakteristik Informan Pendukung

\begin{tabular}{clll}
\hline No & Kode & Informan Pendukung & $\begin{array}{c}\text { Jumlah } \\
\text { (orang) }\end{array}$ \\
\hline 1 & X1 & Koordinator perawat & 1 orang \\
2 & X2 & Perawat pelaksana & 1 orang \\
3 & X3 & Perawat pleasant & 1 orang \\
4 & X4 & Perawat perina & 1 orang \\
5 & X5 & Perawat ruang operasi & 1 orang \\
6 & X6 & Koordinator perawat N1 & 1 orang \\
7 & X7 & Perawat ICU \& HCU & 1 orang \\
8 & X8 & Koordinator perawat N2 & 1 orang \\
9 & X9 & Perawat IGD & 1 orang \\
10 & X10 & Koordinator perawat N3 & 1 orang \\
\hline
\end{tabular}

Sumber : Hasil Wawancara Mendalam

Tabel 1 Karakteristik Informan Kunci

\begin{tabular}{clll}
\hline No & Kode & \multicolumn{1}{c}{ Informan Kunci } & $\begin{array}{c}\text { Jumlah } \\
\text { (orang) }\end{array}$ \\
\hline 1 & X11 & Direktur utama & 1 orang \\
2 & X12 & Direktur operasional & 1 orang \\
3 & X13 & Ex Perawat RSDH & 1 orang \\
\hline
\end{tabular}

Sumber : Hasil Wawancara Mendalam

Informan pada penelitian dipilih bedasarkan karakteristik sesuai tujuan yang ingin dicapai dengan teknik purpasive sampling dan strategi variasi maksimal dengan pertimbangan tertentu. Wawancara dalam penelitian ini dilakukan dengan menggunakan jenis wawancara semi terstruktur dan percakapan informal. Pelaksanaan wawancara semi terstruktur lebih bebas bertanya dan berkomunikasi dengan informan dibandingkan dengan wawancara terstruktur yang terkesan lebih kaku. Bentuk dokumen yang digunakan dalam penelitian ini adalah dokumen resmi jenis dokumen internal yang ada di RSDH Cianjur. Dokumen yang akan dikumpulkan pada penelitian ini berupa daftar nama perawat yang sudah tidak bekerja di RSDH Cianjur tahun 2014, daftar nama perawat yang sudah lama bekerja, dan daftar nama perawat yang baru bekerja, serta dokumen rahasia dari personalia berupa data mengenai sistem penggajian

Alat pengumpulan data yang digunakan dalam penelitian ini adalah dengan menggunakan tape recorder melalui Hand phone dan field notes beserta alat tulis (bolpoint Peneliti melakukan uji coba alat perekam suara sebelum melakukan wawancara dengan merekam suara sendiri lalu diperdengarkan. Setelah mendapatkan hasil wawancara dari informan inti, selanjutnya peneliti melakukan wawancara kepada informan pendukung guna mendapatkan data yang valid dan mengkonfirmasi sistuasi yang terjadi di RSDH Cianjur. Dalam pengumpulan data dari informan pendukung, peneliti mendapatkan sedikit kemudahan mengingat informan pendukung masih berada dalam satu wilayah yaitu di RSDH Cianjur. Tahap terakhir adalah mengumpulkan data dengan direktur RSDH Cianjur. Peneliti mengajukan beberapa alternatif kebijakan yang telah disusun sebelumnya untuk menurunkan angka kejadian turnover perawat di RSDH Cianjur. Kendala yang dihadapi peneliti saat melakukan wawancara dengan direktur adalah faktor kesibukan direktur dan waktu yang terbatas.

Data yang telah berhasil digali dilapangan studi, dikumpulkan dan dicatat dalam penelitian. Untuk menjaga keabsahan data pada penelitian kualitatif diperlukan beberapa strategi untuk menjaga validitas yang dikenal dengan triangulasi. Hasil rekaman wawancara diformat menjadi bentuk verbatim wawancara, 
dan data dokumen dirubah kedalam bentuk skrip analisa dokumen, serta data hasil observasi disusun kedalam tabel hasil observasi. $^{8}$

\section{Hasil dan Pembahasan}

Data karakteristik informan diperoleh dari arsip dan dokumen dari bagian personalia dan bagian departemen keperawatan RSDH Cianjur. Jumlah responden yang digunakan sebanyak 5 orang, karena pada saat dilakukan penelitian sudah terjadi pengulangan informasi oleh informan. Adapun jenis informasi yang digunakan dalam penelitian ini adalah informan kunci dan informan pendukung. Informan pendukung dalam penelitian ini diperoleh dari 8 sumber yaitu : Direktur Utama, Direktur Pelayanan, Manager Pelayanan Medik, Penunjang Medik, Keperawatan, Pemasaran, SDM, Perawat baru bekerja dan Perawat sudah keluar. Adapun temuan penelitian dapat dijabarkan sebagai berikut :

“... disini tidak adanya uang lembur bagi karyawan yang bekerja melebihi waktu kerjanya...." (X2)

\section{Kebijakan operasional terkait dalam menurunkan kejadian turnover perawat di RSDH Cianjur}

Penelitian kualitatif yang dilakukan terkait dengan alternatif kebijakan operasional dalam menurunkan kejadian turnover perawat di RSDH Cianjur, menghasilkan temuan berdasarkan tujuan penelitian yang telah disusun sebelumnya. Hasil analisis tematik mengidentifikasikan 6 tema pada penelitian, yaitu :

1. Sistem kompensasi dan penghargaan

2. Aspek internal

3. Jenjang karir

4. Sistem seleksi dan rekrutmen

5. Kebijakan ikatan kerja

2. Kebijakan operasional terkait alternatif kebijakan operasional dalam menurunkan kejadian turnover perawat di RSDH Cianjur.

Penelitian kualitatif yang dilakukan terkait alternatif kebijakan operasional dalam menurunkan kejadian turnover perawat di RSDH Cianjur menghasilkan tema-tema berdasarkan tujuan penelitian yang telah disusun sebelumnya. Adapun tema-tema tersebut dapat dijabarkan sebagai berikut :

\section{Sistem kompensasi dan penghargaan}

Kompensasi adalah semua balas jasa yang diterima seorang karyawan dari perusahaannya sebagai akibat dari jasa dan tenaga serta pengorbanan waktu yang telah diberikannya karyawan pada perusahaan tersebut. ${ }^{9}$ Seluruh informan menyampaikan sistem kompensasi dan penghargaan belum ada. Beberapa pernyataan informan pendukung terkait dengan kebijakan operasional dalam sistem kompensasi dan penghargaan:

"...jadi karena kompensasi belum setiap bulan tidak keluar tapi setiap tahun itu selalu ada baik itu tunjangan hari raya maupun akhir tahun bonus, akhir tahun itu alhamdulillah selama 2 tahun ini selalu keluar walupun tidak tiap bulan....." (X3)

Kebijakan operasional dalam sistem kompensasi dan penghargaan ini sangat penting, karena merupakan kesejahetraan untuk karyawan khususnya untuk perawat.

Hasil wawancara mendalam yang dilakukan kepada 5 orang berdasarkan hasil rekaman informan yang sudah tidak bekerja di RSDH Cianjur diperoleh bahwa, alasan mereka memutuskan tidak bekerja lagi di RSDH Cianjur adalah ketidaksesuaian antara upah yang diterima dengan kinerja yang telah dilakukan.

“... disini tidak adanya uang lembur bagi karyawan yang bekerja melebihi waktu kerjanya...." (X2)

Berdasarkan hasil rekaman informan merasa kecewa karena ketidaksesuaian penghasilan tambahan yang diperoleh dari RSDH Cianjur seperti tidak adanya uang lembur bagi karyawan yang bekerja melebihi waktu kerjanya. Sehingga persepsi informan pun menjadi negatif terhadap 
manajemen. Informan merasa tenaga mereka hanya dimanfaatkan oleh rumah sakit tanpa pemberian imbalan yang sesuai. Tidak ada penghargaan sama sekali terhadap apa yang saya kerjakan.

Hasil wawancara mendalam yang dilakukan kepada 5 informan yang sudah tidak bekerja di RSDH Cianjur diperoleh bahwa alasan mereka untuk keluar adalah ketidaksesuaian antara beban kerja, tuntutan kerja terlalu tinggi, tanpa diimbangi dengan penghasilan yang sesuai. Informan merasa tidak puas dan kurang nyaman terhadap kondisi kerja seperti itu. Setiap individu yang memasuki suatu organisasi kerja membawa sejumlah harapan dalam dirinya, misalnya ; upah, status, pekerjaan, lingkungan sosial, dan pengembangan dirinya. ${ }^{10}$

“....adanya ketidaksesuaian antara beban kerja, tuntutan kerja terlalu tinggi, tanpa diimbangi dengan penghasilan yang sesuai....” (X12)

\section{Aspek internal}

Aspek internal merupakan kondisi yang berada didalam suatu perusahaan, meliputi : rekan kerja, lingkungan kerja, budaya organisasi, kepuasan terhadap kondisi-kondisi kerja dan kepuasan terhadap kerabat-kerabat kerja, serta gaya kepemimpinan. Hasil wawancara mendalam yang dilakukan kepada 5 informan yang sudah tidak bekerja di RSDH Cianjur diperoleh bahwa alasan mereka untuk keluar adalah ketidaksesuaian antara beban kerja, tuntutan kerja terlalu tinggi, tanpa diimbangi dengan penghasilan yang sesuai. Informan merasa tidak puas dan kurang nyaman terhadap kondisi kerja seperti itu.

“....adanya ketidaksesuaian antara beban kerja, tuntutan kerja terlalu tinggi, tanpa diimbangi dengan penghasilan yang sesuai...." (X12)
Faktor-faktor yang mempengaruhi loyalitas kerja adalah adanya fasilitas kerja, tunjangan kesejahteraan, suasana kerja, serta upah yang diterima dari perusahaan, loyalitas perawat akan tinggi apabila diimbangi dengan pemberian upah yang sesuai dengan beban kerja, dan dengan demikian karyawan akan termotivasi untuk meningkatkan kualitas kerja. ${ }^{11}$

\section{a. Rekan kerja}

Hasil wawancara mendalam yang dilakukan kepada 5 orang informan yang sudah tidak bekerja di RSDH Cianjur mengenai bagaimana rekan kerja saat bekerja di RSDH Cianjur, diperoleh hasil bahwa rekan kerjanya solid, rekan kerjanya baik-baik, kompak, bisa bekerja sebagai tim, berasaskan kekeluargaan, serta melakukan diskusi jika menemukan masalah, baik antar rekan medis maupun rekan kerja dari devisi lain. Hasil ini pun didukung oleh informan pendukung, baik dari perawat yang bekerja lebih dari 5 tahun maupun perawat yang baru bekerja di RSDH Cianjur. Mereka menyatakan bahwa, rekan kerja di RSDH Cianjur semuanya baik, asik-asik, enjoy, bisa bekerja sebagai tim, dan sudah seperti keluarga, dan melakukan diskusi jika terjadi masalah

Berdasarkan hasil observasi yang dilakukan di ruangan poliklinik, Perinata, ICU/HCU, Rawat inap RSDH Cianjur, SDM,OK diperoleh bahwa, semua perawat dapat bekerja dan menyelesaikan pekerjaannya dengan baik. Mereka bekerja sebagai tim dimana saling membantu satu sama lain jika ada teman yang sedang kewalahan merawat pasien. Walaupun kondisi pasien lagi rame dan sibuk, mereka masih bisa untuk tersenyum dan tertawa. Rekan kerja sangat berpengaruh terhadap kejadian turnover perawat, mengingat jika bekerja dalam satu institusi dan mendapatkan rekan kerja yang baik dan 
merasa nyaman, maka seseorang akan bekerja dengan tulus dan senang hati. ${ }^{12}$

\section{b. Lingkungan kerja}

Lingkungan kerja merupakan keadaan sekitar tempat kerja baik secara fisik maupun non fisik yang dapat memberikan kesan yang menyenangkan, mengamankan, menentramkan, dan betah untuk bekerja. ${ }^{13}$ Hasil wawancara mendalam yang dilakukan kepada 5 orang informan yang sudah tidak bekerja di RSDH Cianjur mengenai lingkungan kerja, diperoleh bahwa lingkungan kerja di RSDH Cianjur sangat kondusif. Jika dilihat dari lingkungan kerja fisik terlihat bersih, tidak berisik. Dan dari lingkungan kerja non fisik sangat nyaman dan kondusif, hubungan antar rekan kerja sangat baik, bisa bekerja tim.

Informasi ini tidak hanya diperoleh dari informan kunci saja melainkan diperoleh juga dari informan yang bekerja di RSDH Cianjur lebih dari 5 tahun. Hasil konfirmasi yang dilakukan kepada 5 informan yang masih bekerja di RSDH Cianjur melalui wawancara mendalam diperoleh bahwa kondisi lingkungan kerja di RSDH Cianjur sangat kondusif, dan nyaman sehingga membuat mereka merasa betah untuk bekerja.Hasil observasi yang dilakukan oleh peneliti mengenai lingkungan kerja di RSDH Cianjur diperoleh bahwa, lingkungan fisik sangat bersih, rapi, dari segi pencahayaan baik, dan sangat kondusif untuk bekerja. Dari lingkungan non fisik pun baik, hubungan dengan rekan kerja medis maupun dengan devisi lain terjalin baik, setiap ada masalah diselesaikan dengan cara diskusi untuk mendapatkan pemecahan masalahnya.

\section{c. Budaya organisasi}

Hasil wawancara mendalam yang dilakukan kepada 5 orang informan yang sudah tidak bekerja di RSDH
Cianjur mengenai budaya organisasi, diperoleh bahwa budaya organisasi RSDH Cianjur adalah kekeluargaan, dan saling menghargai dan menghormati dengan sesama rekan kerja, serta mempunyai tradisi yang baik dengan menyediakan akomodasi jika ada rekan kerja yang menikah di luar kota. Karyawan dengan budaya organisasi kekeluargaan akan memiliki keinginan untuk berpindah kerja lebih kecil. ${ }^{14}$

\section{d. Gaya kepemimpinan}

Pengertian gaya kepemimpinan yang menjelaskan bahwa kepemimpinan adalah upaya menggunakan berbagai jenis pengaruh yang bukan paksaan untuk memotivasi anggota organisasi untuk mencapai tujuan tertentu. ${ }^{15}$ Hasil wawancara mendalam yang dilakukan kepada 5 orang informan yang sudah tidak bekerja di RSDH Cianjur mengenai kepemimpinan, diperoleh hasil bahwa sikap pimpinan saat bekerja di RSDH Cianjur selalu mengayomi, merangkul, dan memberi motivasi bawahannya, serta selalu flkesibel dalam pengaturan jadwal dines. Jika dilihat dari segi komunikasi, cara penyampaian informasi jelas, dan jika ada masalah maka pimpinan selalu melakukan diskusi untuk mendapatkan solusi. Dalam hal pembagian tugas sangat adil dan berpatokan pada SOP yang ada. Jika terjadi kelebihan beban kerja, maka atasan akan mencari tenaga perbantuan dari ruangan lain. Jika karyawan merasa puas dengan sikap dan gaya kepemimpinan atasannya, maka karyawan tersebut akan merasa betah untuk bekerja

\section{Jenjang karir}

Kegiatan ini bertujuan untuk mendapatkan suatu posisi jabatan harus mempunyai potensi yang baik dan mendapatkan promosi jabatan dari 
atasan langsung. Untuk melanjutkan pendidikan ketingkat yang lebih tinggi harus melihat situasi diruangan, dan untuk mengikuti pelatihan cukup dipertimbangkan. Hasil wawancara mendalam yang dilakukan kepada 5 orang informan yang sudah tidak bekerja di RSDH Cianjur mengenai jenjang karir, diperoleh bahwa menjelaskan bahwa manfaat dan tujuan dari kegiatan pengembangan sumber daya manusia yaitu Mengurangi turnover, bahwa dengan semakin besarnya komitmen pegawai terhadap organisasi memberikan dampak terhadap adanya pengurangan tingkat turnover ${ }^{16}$ :

“....untuk peningkatan jenjang karir tidak berjalan dengan baik dan sulit untuk sekolah lagi ke jenjang yang lebih tinggi...." (X10).

\section{Sistem seleksi dan rekrutmen}

Hasil wawancara mendalam yang dilakukan kepada informan di RSDH Cianjur mengenai Sistem seleksi dan rekrutmen, diperoleh bahwa :

“....seleksi dan rekrutmen diatur dalam SOP kepegawaian kami, dimana perawat yang melamar ke RSDH mendapatkan informasi dari Web RSDH dan melalui surat lamaran yang dikirim langsung ke RSDH. Sistem di HRD akan menyaring dengan sistem seleksi administrasi yaitu dengan kelengkapan berkas administrasi dengan persyaratan memiliki ijazah minimal DIII perawat, berpengalaman, usia maksimal 35 tahun, memiliki serifikat BTCLS... “ (X11)

Rekrutmen merupakan salah satu fungsi MSDM pada aspek pengadaan tenaga kerja yang khusus mendapatkan calon-calon karyawan untuk kemudian diseleksi mana yang paling baik dan paling sesuai dengan persyaratan yang diperlukan, salah satunya adalah melalui proses rekrutmen. Kesemuanya ini menjadi tugas dan tanggung jawab utama dari departemen SDM. Rekrutmen sebagai usaha mencari dan mempengaruhi calon tenaga kerja agar mau melamar lowongan pekerjaan yang ditawarkan oleh suatu perusahaan. ${ }^{17}$

“.... Di RSDH Cianjur sistem rekrutmen berdasarkan kepada surat lamaran yang masuk, apabila pengadaan karyawan dibutuhkan untuk Bulan April maka perekrutan diambil dari pelamar yang melamar 3 bulan sebelum waktu dibutuhkan, untuk perawat sendiri tidak membuka lowongan pekerjaan karena minat menjadi perawat di RSDH sendiri banyak...." (X12)

\section{Kebijakan ikatan kerja}

Ikatan kerja untuk setiap Rumah Sakit berbeda-beda tergantung pada independent dan SOP tiap rumah Sakit. Pada RSDH Cianjur, kebijakan ikatan kerja adalah dengan adanya pengangkatan menjadi karyawan tetap dimana tenaga honorer tersebut telah menjalani masa percobaan selama 3 bulan, memiliki kelakuan dan kinerja yang bagus kemudian dapat dinilai pada 2 tahun pertama maka perawat tersebut dapat diangkat menjadi karyawan tetap. Hal ini sesuai dengan sumber dari informan yang mengatakan bahwa :

“....untuk pelamar melalui masa percobaan 3 bulan pertama, tergantung kepada kebutuhan apakah ingin menjadi karyawan tetap atau bagaimana. Kalau karyawan tetap atau karyawan kontrak. Jadi RSDH punya 2 kategori yaitu PKWTC (karyawan kontrak) dan PKWT (karyawan tetap) berlaku 3 bulan pertama, kalau dengan karyawan kontrak maka dikontrak sesuai dengan target waktu (maksimal kontrak $2 x) \ldots ”(X 12)$ 


\section{Faktor Lain Penyebab Turnover Perawat di RSDH Cianjur}

Faktor lain penyebab turnover perawat adalah temuan baru hasil penelitian yang tidak termasuk kedalam konsep teori. Adapun penyebab lain turnover perawat di RSDH Cianjur dapat dijabarkan sebagai berikut :

\section{a. Faktor Jarak}

Jarak merupakan angka yang menunjukan seberapa jauh seseorang melakukan pejalanan melalui lintasan tertentu. Yang dimaksud dengan faktor jarak dalam penelitian ini adalah seberapa lama waktu tempuh sesorang untuk sampai ketujuannya, dalam hal ini adalah dari rumah informan sampai ke RSDH Cianjur. Hasil wawancara mendalam yang dilakukan kepada 5 informan yang sudah tidak bekerja lagi di RSDH Cianjur, terdapat 2 informan yang menyatakan bahwa jarak rumah mereka dengan tempat kerja terlalu jauh, dan memerlukan waktu yang cukup lama untuk sampai di RSDH Cianjur, dan memerlukan biaya yang besar untuk menuju ketempat kerja mengingat harga bahan bakar minyak sudah meningkat, sehingga penghasilan mereka habis untuk ongkos saja. Selain itu, faktor bahaya dijalanan yang akan dihadapi cukup tinggi. yang menyatakan bahwa terdapat hubungan yang bermakna antara jarak tempuh dengan kejadian turnover perawat di PK saint Carolus. Jarak rumah sangat berpengaruh sekali dengan kejadian turnover, mengingat resiko yang akan terjadi dalam perjalanan sangat tinggi. ${ }^{18}$

Faktor jarak sangat berpengaruh dengan kerjadian turnover, karena dengan jarak rumah dengan tempat kerja sangat jauh, maka resiko dan bahaya lalu lintas yang akan dihadapi oleh pekerja sangat besar yang akan berpengaruh terhadap kualitas kerja. Konsep usulan yang dapat diberikan kepada manajemen RSDH Cianjur adalah pada saat melakukan proses seleksi dan rekrutment, perlu ditekankan pada faktor jarak dengan menanyakan jarak rumah dengan tempat kerja, berapa lama perjalanan yang ditempuh, dan kaitan antara jarak tempuh dengan penghasilan yang akan diterima setiap bulannya, dengan demikian setidaknya dapat menurunkan angka kejadian turnover perawat di RSDH Cianjur.

\section{b. Faktor Keluarga}

Hasil wawancara mendalam yang dilakukan kepada 5 informan yang sudah tidak bekerja lagi di RSDH Cianjur, diperoleh bahwa 2 orang informan keluar dari RSDH dengan alasan keluarga seperti : mau pulang kekampung halaman untuk merawat orang tua, ingin membangun dan memperbaiki kampung halaman. Berdasarkan peneltian di rumah sakit Harapan Bunda Batam tentang turnover tenaga perawat menyebutkan ingin keluar lebih dekat dengan rumah. ${ }^{19}$ Alasan untuk merawat orang tua merupakan alasan yang sudah klasik, kebanyakan orang-orang yang bekerja merantau jauh dari sanak keluarga suatu saat pasti kan kembali kekampung halamannya untuk merawat orang tuanya, ingin berbakti terhadap orang tuanya.

Konsep usulan yang dapat diberikan kepada manajemen RSDH Cianjur terkait dengan faktor keluarga adalah menanyakan sejelas mungkin terkait masalah keluarga seperti : berasal dari mana, tinggal dengan siapa, cepat atau lambat apakah ada rencana untuk kembali ke kampung halaman, jika orang tua dikampung sakit apa yang akan dilakukan. Untuk mengurangi kejadian turnover perawat karena fator keluarga, maka dapat diantisipasi dengan membuat ikatan kerja atau ikatan dines dengan materai yang ditandatangani oleh calon pegawai dan pihak manajemen, sehingga jika karyawan mengajukan pengunduran diri, maka karyawan tersebut akan dikenakan sanksi.

\section{c. Mengikuti Program Mempunyai Keturunan}

Hasil wawancara mendalam yang dilakukan kepada informan yang sudah tidak bekerja di RSDH Cianjur, diperoleh bahwa 1 orang informan yang mengatakan alasan keluar dari RSDH Cianjur adalah atas anjuran dari suami karena mau mengikuti program mempunyai keturunan. Mengingat lokasi rumah dengan tempat kerja sangat 
jauh dan membuat kondisi fisiknya terlalu capek, serta banyak rintangan yang harus dihadapi dalam perjalanan sehingga mengeluh stress dalam perjalanan. Salah satu faktor yang menyebabkan susahnya mempunyai keturunan adalah faktor stres. $^{20}$

Pekerja dengan jarak rumah jauh dengan lokasi kerja, maka akan banyak mengalami stres dalam perjalanan, mengingat kondisi jalan raya di cianjur sangat sepi pada malam hari sehingga dapat memicu stress. Selain itu terdapat faktor lain yang dapat memicu terjadinya stress perawat meliputi beban kerja perawat terlalu tinggi dan tuntutan rumah sakit sangat tinggi. Sehingga dapat mempengaruhi kondisi kesuburan seseorang. Konsep usulan yang dapat diberikan kepada manajemen RSDH Cianjur terkait faktor ini adalah dengan menanyakan status perkawinan, sudah punya anak berapa, dan ada rencana untuk mempunyai atau mengikuti program memiliki keturunan. Karena faktor ini akan mempunyai potensi untuk memicu terjadinya turnover.

\section{d. Hobby}

Hasil wawancara mendalam yang dilakukan kepada informan yang sudah tidak bekerja lagi di RSDH Cianjur, diperoleh bahwa 1 orang informan mengatakan keluar dengan alasan hobby. Informan tersebut ingin menjalankan hobbinya dalam bekerja seperti mengajar dan traveling. Informan memiliki jiwa untuk menjadi seorang marketing, menyukai dunia kerja seperti berhadapan dan berbicara dengan orang banyak untuk membagi informasi. Secara teoritis, tidak selalu hobi itu sangatlah luas diartikannya dalam kegiatan yang kita sesuailkan dengan kemampuan dan keinginan masingmasing. ${ }^{21}$

\section{e. Tawaran kerja di tempat yang lain}

Hasil wawancara mendalam yang dilakukan kepada informan inti diperoleh hasil bahwa, 1 orang informan lulus menjadi Pegawai Negeri Sipil (PNS), dengan menjadi PNS maka ada pengakuan dan penghargaan tentang status pendidikan, serta kualitias hidup terjamin. Selain itu diperoleh informasi dari seorang informan mendapatkan pekerjaan baru dibidang alkes produk spesialis yang dapat memberikan gaji yang jauh lebih besar dibandingkan dengan RSDH Cianjur.

Hal ini terjadi karena semua karyawan pasti ingin mendapatkan yang terbaik, baik dari segi penghasilan, penghargaan dan kesempatan untuk mengembangkan diri untuk meningkatkan kualitas hidup. Hasil penelitian ini sejalan dengan penelitian yang dilakukan di Rumah Sakit Ibnu Sina, diperoleh bahwa faktor yang mempunyai hubungan bermakna dengan kejadian turnover perawat yaitu faktor eksternal berupa ketersediaan lapangan pekerjaan di institusi lain. Dengan demikian akan berpotensi untuk terjadinya turnover. ${ }^{22}$

\section{f. Masa Transisi}

Hasil wawancara mendalam yang dilakukan kepada informan inti diperoleh bahwa 3 informan mengatakan alasan mereka mengundurkan diri dari RSDH Cianjur adalah adanya masa peralihan RSDH Cianjur dengan perusahaan lain, yang mengakibatkan banyak perubahan. Salah satunya adalah perubahan pada peraturan perusahaan dan perubahan tunjangan kesehatan. Sehingga informan merasakan ketidakpuasan dengan hal ini yang dianggap merugikan karyawan. Perubahan adalah suatu proses dimana terjadinya peralihan atau perpindahan dari status tetap (statis) menjadi status yang bersifat dinamis. Artinya dapat menyesuaikan diri dari lingkungan yang ada Mother Instink. ${ }^{23}$ Bagi sebagian individu perubahan dapat dipandang sebagai suatu motivator dalam meningkatkan prestasi atau penghargaan.

\section{Perasaan Saat Bekerja di RSDH Cianjur}

Hasil wawancara mendalam yang dilakukan kepada 5 orang informan yang sudah tidak bekerja di RSDH Cianjur, 
mereka mempunyai perasaan yang sama saat bekerja yaitu perasaan senang dan nyaman. Perasaan senang dan nyaman ini juga dirasakan oleh informan pendukung, baik dari perawat yang bekerja lebih dari 5 tahun maupun perawat yang baru bekerja di RSDH Cianjur. Perusahan hendaknya dapat mencerminkan kondisi yang mendukung kerja sama antara tingkat atasan, bawahan maupun yang memiliki status jabatan yang sama di perusahaan. Kondisi yang hendaknya diciptakan adalah suasana kekeluargaan, komunikasi yang baik dan pengendalian diri. Membina hubungan yang baik antara sesama rekan kerja, bawahan maupun atasan harus dilakukan karena kita saling membutuhkan. Hubungan kerja yang terbentuk sangat mempengaruhi psikologis karyawan.

\section{Alasan Perawat Baru Bekerja di RSDH Cianjur}

Hasil wawancara mendalam yang dilakukan kepada 5 orang informan yang baru bekerja di RSDH Cianjur diperoleh bahwa alasan mereka bekerja adalah karena faktor jarak rumah dengan rumah sakit dekat, selain itu mereka menyukai pelajaran jantung sehingga mereka tertarik untuk bekerja di RSDH Cianjur. Selain itu terdapat faktor promosi dari kakak senior tentang RSDH Cianjur. Individu akan bisa bekerja dengan baik apabila bekerja sesuai dengan minta dan keinginannya. Mereka akan termotivasi untuk belajar dengan giat tentang kardiovaskuler, sehingga dapat meningkatkan kualitas pelayanan.

\section{Merumuskan Analisis Kebijakan Operasional}

Perumusan analisis kebijakan dalam penelitian ini mengacu pada konsep yang menggunakan enam langkah dalam merumuskan analisis kebijakan yang sering dikenal dengan A Basic Policy Analysis Process. $^{24}$ Tahap-tahap penerapan konsep dalam penelitian ini dapat dijabarkan sebagai berikut :

\section{Langkah pertama Mendefinisikan, verifikasi masalah yang terjadi}

Pada tahap ini, peneliti mengumpulkan beberapa masalah dan data-data terkait dengan masalah yang sedang terjadi di RSDH Cianjur.

Masalah yang sering terjadi di rumah sakit yang menyangkut tenaga keperawatan dan berpengaruh terhadap kualitas pelayanan adalah masalah pergantian karyawan dalam suatu organisasi atau turnover. Angka kejadian turnover di RSDH Cianjur mengalami peningkatan dari tahun ke tahun, sehingga akan menimbulkan banyak kerugian dari segi biaya dan waktu.

Pada saat penelitian dilakukan, ditemukan beberapa faktor yang menyebabkan perawat RSDH Cianjur melakukan turnover. Sehingga perlu dilakukan perbaikan untuk menurunkan angka kejadian turnover perawat RSDH Cianjur. Adapun faktor-faktor tersebut adalah :

a. Ketidakpuasan dengan kompensasi yang diterima

b. Aspek internal seperti beban kerja yang terlalu berat, tuntutan kerja tinggi, dan kurangnya penghargaan

c. Faktor jarak

d. Faktor keluarga

e. Hobby

f. Tawaran kerja ditempat yang lain

g. Masa transisi

\section{Langkah kedua Menetapkan dan Penerapan Kriteria Isu}

Selanjutnya dari tujuh faktor tersebut dilakukan pemilihan isu aktual yang memenuhi kriteria sebagai berikut :

1) Berdasarkan Urgency ( Mendesak), isu perlu dibahas dikaitkan waktu yang tersedia.

2) Seriousnesses (Tingkat keseriusan), isu tersebut perlu dibahas berdasarkan akibat yang timbul dari penundaan pemecahan masalah yang mengakibatkan isu tersebut semakin berkembang.

3) Growth (Kecenderungan berkembang) , isu menjadi berkembang makin memburuk kalau dibiarkan. Bisa dilihat dari tabel sebagai berikut: 
Tabel 1 Penerapan Kriteria Alternatif Kebijakan Operasional

\begin{tabular}{clccccc}
\hline No & \multicolumn{1}{c}{ Isu } & $\mathrm{U}$ & $\mathrm{S}$ & $\mathrm{G}$ & Total & Ranking \\
\hline 1 & Ketidakpuasan dengan kompensasi yang diterima & 5 & 5 & 5 & 15 & $\mathrm{I}$ \\
2 & $\begin{array}{l}\text { Aspek internal seperti beban kerja yang terlalu berat, } \\
\text { tuntutan kerja tinggi, dan kurangnya penghargaan }\end{array}$ & 5 & 4 & 3 & 12 & $\mathrm{III}$ \\
3 & $\begin{array}{l}\text { Tidak adanya peningkatan jenjang karir } \\
4\end{array}$ & 5 & 4 & 4 & 13 & $\mathrm{II}$ \\
& $\begin{array}{l}\text { Sistem seleksi dan rekrutmen karyawan harus memiliki } \\
\text { sertifikat keperawatan /BTCLS }\end{array}$ & 3 & 3 & 3 & 9 & $\mathrm{~V}$ \\
& $\begin{array}{l}\text { Untuk karyawan kontrak maksimal 2 tahun dan dapat } \\
\text { sanksi berupa 2x sisa kontrak }\end{array}$ & 3 & 4 & 4 & 11 & IV \\
\hline
\end{tabular}

Tabel 3 Evaluasi Faktor Internal dan Eksternal Keterkaitan

\begin{tabular}{|c|c|}
\hline NO & FAKTOR INTERNAL DAN EKSTERNAL \\
\hline & STRENGHTS (KERUATAN) \\
\hline 1 & Pembayaran gaji karyawan selalu tepat waktu \\
\hline & Semua karryawan mendapatkan tunjangan kesehatan \\
\hline 3 & $\begin{array}{l}\text { Adanya pembagian insentif hari raya kepada semua } \\
\text { karvawan }\end{array}$ \\
\hline
\end{tabular}

WEAKNESSES (KELEMAHAN)

4 Belum mempunyai standarisasi system pengoajan

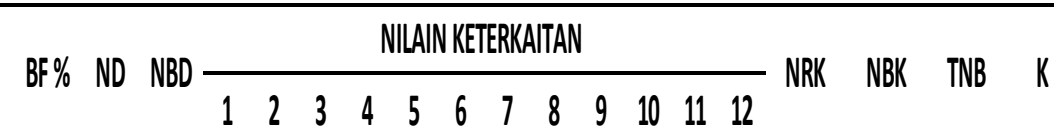

5 Jumlah tunjangan kesehatan yang diberikan terbatas 6 Ketidakjelasan dalam system perhitungan pembagian insentif

$$
\begin{aligned}
& 27 \% \\
& \begin{array}{lllllllllllllllll}
27 \% & 4 & 1,07 & 5 & 5 & 5 & 4 & 4 & 5 & 5 & 4 & 4 & 4 & 5 & 4,09 & 1,09 & 2,16
\end{array} \\
& \begin{array}{lllllllllllllllll}
20 \% & 3 & 0,60 & 4 & 5 & 5 & 5 & 5 & 5 & 5 & 4 & 4 & 5 & 3 & 4,18 & 0,84 & 1,44
\end{array} \\
& 2,73 \\
& 12,91 \quad 3,16 \quad 5,90
\end{aligned}
$$

OPPORTUNITIES (PELUANG)

7 Banyaknya perawat yang baru lulus

8

Adanya beasiswa sekolah dari manajemen RSDH Cianjur

9

Lokasi kimik strategis dapat dilalui banyak angkutan umum

$\begin{array}{llllllllllllllllll}13 \% & 2 & 0,26 & 1 & 3 & 3 & 2 & 2 & 2 & 2 & 3 & 3 & 2 & 1^{\prime} & 2,09 & 0,27 & 0,53\end{array}$

$\begin{array}{lllllllllllllllll}13 \% & 2 & 0,26 & 3 & 1 & 2 & 2 & 2 & 1 & 3 & 2 & 2 & 1 & 2 & 1,64 & 0,21 & 0,47\end{array}$

$\begin{array}{lllllllllllllllll}13 \% & 2 & 0,26 & 2 & 2 & 1 & 1 & 2 & 2 & 2 & 3 & 3 & 2 & 2 & 1,82 & 0,24 & 0,50\end{array}$

$\begin{array}{llll}0,78 & 5,55 & 0,72 & 1,50\end{array}$

Threats (ANCAMAN)

10 Banyak kompetitor yang berani memberikan gajj besar

11 Susah mencari tenaga perawat siap pakai

12 Munculnya rumah sakit baru dengan bidang yang sama

$20 \% \quad 3 \quad 0,6050 \begin{array}{llllllllllllll} & 5 & 5 & 5 & 4 & 5 & 5 & 5 & 5 & 5 & 4 & 4,36 & 0,87 & 1,47\end{array}$

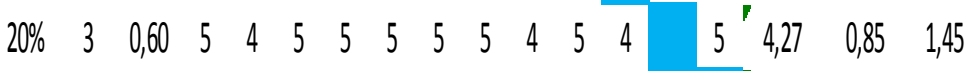

$\begin{array}{lllllllllllllllll}20 \% & 3 & 0,60 & 4 & 5 & 4 & 5 & 4 & 4 & 4 & 5 & 5 & 5 & 5 & 4,18 & 0,84 & 1,44\end{array}$ 1,80 $12,82 \quad 2,56 \quad 4,36$ 
Tabel 2 Formulasi Strategi SWOT

\begin{tabular}{|c|c|c|}
\hline EKSTERNAL & $\begin{array}{ll}\text { KEKUATAN (STRENGHTS) : } \\
\text { 1. } \\
\text { Pembayaran gaji karyawan } \\
\text { selalu tepat waktu } \\
\text { 2. } \begin{array}{l}\text { Semua karyawan mendapatkan } \\
\text { tunjangan kesehatan }\end{array} \\
\text { 3. } \begin{array}{l}\text { Adanya pembagian insentif hari } \\
\text { raya kepada semua karyawan }\end{array}\end{array}$ & \begin{tabular}{ll}
\multicolumn{1}{c}{ KELEMAHAN } \\
(WEAKNESSES): \\
1. $\begin{array}{l}\text { Belum mempunyai } \\
\text { standarisasi system } \\
\text { penggajian }\end{array}$ \\
2. $\begin{array}{l}\text { Jumlah tunjangan } \\
\text { kesehatan yang diberikan } \\
\text { terbatas }\end{array}$ \\
3. $\begin{array}{l}\text { Ketidakjelasan dalam } \\
\text { system perhitungan } \\
\text { pembagian insentif }\end{array}$ \\
\end{tabular} \\
\hline $\begin{array}{l}\text { PELUANG (OPPORTUNITIES): } \\
\text { 1. } \\
\text { 2. } \\
\text { Adanyaknya perawat yang baru lulus } \\
\text { manajemen RSDH Cekolah dari } \\
\text { 3. } \begin{array}{l}\text { Lokasi RSDH Cianjur strategis dapat } \\
\text { dilalui banyak angkutan umum }\end{array}\end{array}$ & $\begin{array}{l}\text { STRATEGI SO : } \\
\text { Mengoptimalkan pembayaran gaji } \\
\text { yang tepat waktu untuk mendapatkan } \\
\text { perawat yang baru lulus }\end{array}$ & $\begin{array}{l}\text { STRATEGI WO: } \\
\text { Memperbaiki standarisasi } \\
\text { system penggajian untuk } \\
\text { mendapatkan perawat yang baru } \\
\text { lulus }\end{array}$ \\
\hline $\begin{array}{l}\text { ANCAMAN (THREATS) : } \\
\text { 1. Banyak kompetitor yang berani } \\
\text { memberikan gaji besar } \\
\text { 2. Sulitnya mencari tenaga perawat siap } \\
\text { pakai } \\
\text { 3. Munculnya rumah sakit baru dengan } \\
\text { bidang yang sama }\end{array}$ & $\begin{array}{l}\text { STRATEGI ST : } \\
\text { Memanfaatkan pembayaran gaji yang } \\
\text { tepat waktu untuk menghadapi } \\
\text { competitor yang berani memberikan } \\
\text { gaji yang besar }\end{array}$ & $\begin{array}{l}\text { STRATEGI WT: } \\
\text { Memperbaiki system } \\
\text { standarisasi system penggajian } \\
\text { untuk menghadapi kompetitior } \\
\text { yang berani memberikan gaji } \\
\text { besar. }\end{array}$ \\
\hline
\end{tabular}

3. Langkah ke tiga mengidentifikasi alternatif kebijakan

Masalah utama yang menyebabkan tingginya angka kejadian turnover perawat di RSDH Cianjur adalah ketidakpuasan dengan kompensasi yang diterima. Untuk mengatasi masalah tersebut, maka dapat dirumuskan beberapa alternatif kebijakan guna menurunkan angka kejadian turnover perawat. Sesuai dengan menggunakan analisa SWOT, maka kebijakan operasional yang diajukan kepada Manajemen RSDH Cianjur untuk menurunkan kejadian turnover perawat dengan memperbaiki sistem penggajian. dimana strategi yang digunakan untuk menurunkan angka kejadian turnover perawat dengan meningkatkan upah dan tunjangan. ${ }^{25}$ Sesuai dengan perumusan masalah utama dengan menggunakan analisa SWOT, maka kebijakan operasional yang diajukan kepada Manajemen RSDH Cianjur untuk menurunkan kejadian turnover perawat adalah dengan memperbaiki sistem penggajian.

4. .Langkah ke empat Evaluasi alternatif kebijakan

Hasil wawancara mendalam yang dilakukan kepada direktur RSDH Cianjur tentang pengajuan usulan kebijakan operasional diperoleh hasil bahwa, pada dasarnya Direktur RSDH Cianjur menyetujui adanya perbaikan sistem penggajian yang akan disesuaikan dengan standarisasi yang berlaku pada perusahaan yang baru. Tentunya akan disesuaikan dengan tingkat pendidikan dan lama bekerja.

5. Pemantauan dan evalusi kebijakan yang diimplementasikan

Kegiatan pemantauan dan evaluasi kebijakan operasional dapat digunakan sebagai materi penelitian selanjutnya untuk menilai keefektivitasan kebijakan operasional kejadian turnover perawat berupa darf SOP Remunrasi Perawat di Rumah Sakit di Dr. Hafiz Cianjur untuk menurunkan sebagai berikut : 
Tabel 4. Draf Usulan Rekomendasi Kebijakan Remunerasi Perawat di Rumah Sakit Dr. Hafiz Cianjur

\begin{tabular}{|c|c|c|}
\hline & SOP R & RUMAH SAKIT Dr. HAFIZ CIANJUR \\
\hline & No. Dokumen & Ditetapkan oleh Direktur RSDH Cianjur \\
\hline & No.Revisi & \\
\hline & Tahun berlaku & \\
\hline & Halaman & \\
\hline & & dr. RENYTA AMELIA, MARS \\
\hline 1. Pengertian & Prosedur ini $\mathrm{m}$ & untuk melakukan remunerasi perawat \\
\hline 2. Tujuan & $\begin{array}{l}\text { a. Tujuan umur } \\
\text { Adalah Sejur } \\
\text { - Bekerja par } \\
\text { - Mencapai } 1 \\
\text { • Mendukun } \\
\text { b. Tujuan khus } \\
\text { 1. Memper } \\
\text { 2. Memper } \\
\text { "turnove } \\
\text { 3. Mendap } \\
\text { 4. Memotiv } \\
\text { 5. Menjami } \\
\text { 6. prestasi } 1 \\
\text { 7. Mengen } \\
\text { 7. Sarana u }\end{array}$ & $\begin{array}{l}\text { Organisasi Kepada Pegawai Atas Kesediaan : } \\
\text { menaati peraturan yang ditetapkan } \\
\text { buhan serta pengembangan usaha organisasi } \\
\text { fikasi tinggi } \\
\text { ng baik dan berprestasi serta mencegah } \\
\text { hh perilaku yang diinginkan } \\
\text { n dengan yang lainnya berdasarkan kinerja dan } \\
\text { RS }\end{array}$ \\
\hline 3. Kebijakan & $\begin{array}{ll}1 . & \text { Peratur } \\
& \text { Peneta }\end{array}$ & $\begin{array}{l}\text { MK No. 73/PMK.05/2007 tentang Pedoman } \\
\text { engelola, Dewan Pengawas }\end{array}$ \\
\hline 2. Referensi & Pedoman Remı & \\
\hline 3. Prosedur & $\begin{array}{l}\text { Ketetapan remı } \\
\text { performance, d } \\
\text { 1. Menetapl } \\
\text { perawat c } \\
\text { NERS } \\
\text { 2. Menetapl } \\
\text { berdasark } \\
\text { a. Men } \\
\text { pera } \\
- \\
- \\
- \\
- \\
- \\
\text { Men } \\
\text { Utan } \\
\text { peng } \\
\text { seba } \\
\text { a. } \\
\text { b. } \\
\text { c. } \\
\text { d. } \\
\text { e. } \\
\text { Men } \\
\text { berd } \\
\text { kete } \\
\text { a. }\end{array}$ & $\begin{array}{l}\text { an perhitungan 3P (Pay for position, pay for } \\
\text { rhitungan remunerasi di RSDh diantaranya : } \\
\text { erdasarkan Ketetapan Diretktur RSDH, dimana } \\
\text { apkan pada grading poin } 6 \text { - } 10 \text { pada kelompok } \\
\text { asarkan kinerja dan tugas pokok perawat } \\
\text { For Performance terdiri dari } 5 \text { langkah, yaitu : } \\
\text { dai dengan Ketetapan Direktur RSDH bahwa JV } \\
\text { dividu) perawat sesuai Ketetapan Direktur } \\
\text { ponen. Dimana IKI merupakan capaian } \\
\text { da saaat bertugas, dengan kriteria penilaian } \\
1,25 \\
5 \\
0 \\
\text { - } 0,25 \\
\text { nit) yaitu indeks penilaian unit kerja } \\
\text { kerja perawat di rumah sakit. Berdasarkan } \\
\text { itetapkan IKU sebagai berikut : }\end{array}$ \\
\hline
\end{tabular}




\begin{tabular}{|l|l|}
\hline & $\begin{array}{l}\text { b. Baik Sekali indeks kinerja 0,76-1 } \\
\text { c. Cukup indeks kinerja 0,51-0,75 } \\
\text { d. Kurang indeks kinerja 0,26-0,50 } \\
\text { e. Kurang sekali indeks kinerja 0-0,25 } \\
\end{array}$ \\
& $\begin{array}{l}\text { Menetapkan PIR (Poin Indeks Rupiah) satuan rupiah yang ditetapkan oleh Direktur } \\
\text { Utama RSDH untuk perawat dengan besaran Rp.7000 } \\
\text { 3. Menetapkan memasukan indeks-indeks yang telah ditetapkan ke dalam rumus (70\% x } \\
\text { JV x PIR x IKI x IKU) }\end{array}$ \\
\hline 4. Uraian Terkait & $\begin{array}{l}\text { 1. Pengelola program perawat } \\
\text { 2. Perencanaan perawat }\end{array}$ \\
& $\begin{array}{l}\text { 3. Manajer Keperawatan } \\
\text { 4. Direktur RSDH }\end{array}$ \\
\hline
\end{tabular}

\section{Kesimpulan}

Permasalahan kebijakan operasional yang ditemukan adalah belum adanya kebijakan operasional mengenai standarisasi sistem penggajian, tunjangan kesehatan yang diberikan masih terbatas dan ketidakjelasan dalam sistem perhitungan pembagian insentive.

Alternatif rekomendasi kebijakan operasional antara lain pembuatan SOP (tahapan pelaksanaan kegiatan di RSDH) serta transparansi dalam sistem insentive perawat. Pembuatan SOP merupakan alternatif rekomendasi kebijakan operasional yang paling tepat dalam mengurangi kejadian turnover perawat di RSDH Cianjur.

\section{Saran}

Diharapkan kepada direktur RSDH Cianjur dapat memperbaiki sistem penggajian, dan mengingat tingginya angka kejadian turnover perawat terjadinya banyak kerugian bagi rumah sakit baik dari segi biaya. Selain itu diharapkan kepada manajemen RSDH Cianjur, memperbaiki sistem seleksi dan rekrutment, dan membuat standarisasi sistem seleksi dan rekrutment. Diharapkan manajemen RSDH Cianjur mempunyai ketegasan mengenai sistem kontrak bagi karyawan baru, dan membuat perjanjian yang jelas dengan karyawan sehingga dapat mencegah tingginya angka kejadian turnover perawat.

\section{Daftar Pustaka}

1. Ali, Zainuddin. Metode Penelitian Hukum. Jakarta. Sinar Grafika. 2011.

2. Andini, Rita. Analisis Pengaruh Kepuasan Gaji, Kepuasan Kerja, Komitmen Organisasi terhadap Turnover di Rumah Sakit Roemani Muhammadnuhunh Semarang (Tesis). Program Magister Manajemen Universitas Diponegoro, Semarang. 2006.

3. Aryanto, Bambang. Faktor-Faktor Yang Berhubungan Dengan Kecendrungan Turnover Perawat Di Rumah Sakit Islam Ibnu Sina Yarsi
Sumbar Bukit Tinggi (Skripsi). PSIK Universitas Andalas, Sumatra barat. 2011.

4. Elleke, Rosamey. Faktor-Faktor Yang Mempengaruhi Kejadian Turnover Perawat Pelaksana Tahun 2009 Di Rumah Sakit Bhakti Yudha Depok (Tesis). FKM Universitas Indonesi, Jakarta. 2010.

5. Gillies, D. A. Manajemen keperawatan suatu pendekatan sistem / Nursing manajement a sistem approach. Second Edition. Philadelphia: WB Saunders Company. 1998.

6. Unit SDM RSDH. Data recruitment, Karyawan.Jawa Barat.2009.

7. Creswell, John W. Research Design Pendekatan Kualitatif, Kuantitatif, dan Mixed. Yogyakarta : Penerbit Pustaka Pelajar. 2010.

8. Mukhtar. Metode Praktis Penelitian Kualitatif. Jakarta : GP Press Group.2013.

9. Singodimedjo, Markum. Manajemen Sumber Daya Manusia. Surabaya: SMMAS. 2000.

10. Novliadi, Ferry. Turnover Karyawan Ditinjau Dari Budaya Perusahaan Dan Kepuasan Kerja (Tesis). Fakultas Kedokteran Universitas Sumatra Utara, Medan. 2007.

11. Budiharjo, Kadarwati . Metodologi dan Metode Penelitian Eksperimental. Yogyakarta: Koordinasi Perguruan Tinggi Swasta Wilayah V. 2003

12. Alex S. Nitisemito, Manajemen Personalia, Edisi kedua, Ghalia. Indonesia.2001.

13. Supardi. Metode Penelitian Ekonomi dan Bisnis. Yogyakarta: UII Press 2005.

14. Andini, Rita. Analisis Pengaruh Kepuasan Gaji, Kepuasan Kerja, Komitmen Organisasi terhadap Turnover di Rumah Sakit Roemani Muhammadnuhunh Semarang (Tesis). Program Magister Manajemen Universitas Diponegoro, Semarang.2006.

15. Gibson, J.L. Organisasi Perilaku, Struktural dan Proses. Jakarta : Binarupa Aksara.1996.

16. Manullang, Marihot. Manajemen Personalia. Yogyakarta : Gadjah Mada University Press.2006.

17. Hasibuan, Melayu. Manajemen Sumber Daya Manusia, Jakarta : PT Bumi Angkasa.2007.

18. Jusuf,F. Kajian Terhadap Kecenderungan turnover Perawat di Pelayanan Kesehatan Sint 
Carolus (Tesis). FKM Universitas Indonesia, Depok. 2010.

19. Haryati. Turnover Tenaga Perawat di Rumah Sakit Harapan Bunda Batam(Tesis). Universitas Gadjah Mada, Yogyakarta.2007.

20. Soehatman,R.2010. Sistem Manajemen Keselamatan dan Kesehatan Kerja OHSAS 18001. Dian Rakyat, Jakarta.

21. Rini,M. 2006. 120 Solusi Mengelola Keuangan Pribadi. Jakarta : PT Elex Media Komputid

22. Aryanto, Bambang Faktor-Faktor Yang Berhubungan Dengan Kecendrungan Turnover Perawat Di Rumah Sakit Islam Ibnu Sina Yarsi Sumbar Bukit Tinggi (Skripsi). PSIK Universitas Andalas, Sumatra Barat.2011.

23. Sullivan, Eleanor J, and Phillip J. Decker. Effective Leadership and Management in Nursing. Upper Saddle River, NJ: Prentice Hall, 2001

24. Nugroho, Riant. Public Policy Dinamika Kebijakan, Analisis Kebijakan, Manajemen Kebijakan. Jakarta : PT Elex Media Komputido.2011.

25. Hatton, E., \& Dresser, L. Caring about caregivers reducing turnover of frontline health care workers in South Central Wisconsin. Diunduh 21 Oktober 2014 pukul 13.00 wib dari http://www.cows.org/pdf/rp-jwfcna.pdf.2003. 
